\title{
TEACHER'S INSTRUCTIONAL BEHAVIOUR IN INSTRUCTIONAL MANAGEMENT AT ELEMENTARY SCHOOL REVIEWED FROM PIAGET'S COGNITIVE DEVELOPMENT THEORY
}

\author{
Ni Putu Eni Astuti \\ STKIP Suar Bangli \\ Bangli, Bali \\ putu.eniastuti@gmail.com
}

\begin{abstract}
This writing aimed at (1) describing the importance of teacher to review instructional management at elementary school based on Piaget's cognitive development theory; and (2) describing teacher's instructional behavior in managing instructional at elementary school reviewed from Piaget's cognitive development theory. In general, Piaget' cognitive development theory divides children' cognitive development into four stages. In the elementary school ages of 7 to 11 or 12 years old, Piaget classified the cognitive development into concrete operational marked by the use of clear and logic rules. The children implement logic thinking on concrete object, yet abstract or hypothetical. Although the intelligence of this step has been advanced, the way of thinking of the children is still limited because still based on concrete object. Therefore, teacher should comprehend the importance of concrete operational instructional at elementary school so the children could maximally achieve the learning goal in accordance to their thinking level that they acquire. The suggestion that can be proposed is that the teacher should synergize the characteristics of elementary school students in concrete operational stage with the instructional readiness in the steps of planning, implementation and evaluation.
\end{abstract}

Key words: teacher's instructional behavior, concrete operational stage.

\section{INTRODUCTION}

Indonesia's Regulation at UU No. 20 in 2003 stated that elementary school is an educational level which become a base for the students to enter secondary level. It means elementary school is an education level which underlies high level education (high school). This level is intended for seven years old children by the assumption of these children have comprehension level and education needs in accordance to themselves. Elementary education is indeed held for giving basic knowledge, attitude and skills for the children. This elementary education is further developed to improve their quality. We should understand the definition of elementary school so we can follow every activity in accordance to the students' development in this level. 
According to Piaget, 7 to 11 or 12 years old children in Elementary School are in the stage of concrete operational [1]. It is stated as concrete operational because in this stage, the students are able to think logically, but still limited on concrete things, which means solving problem that they directly face.

Considering this condition, the teacher should understand how the students' thinking ability in this phase. Teacher's instructional behavior should concern students' thinking development stages on the concrete operational stage and implementing personal and social constructivism learning approach, by concretizing learning close to students' environment, so the learning would be real for the students and indeed can be understood in their development stages.

Concrete media is anything that real and can be used to deliver a message from the sender to the receiver so it would stimulate the thinking, feeling, and students' interest which finally the learning process can be more effective and efficient to achieve the learning goals. There are three concepts of concrete learning media such as (1) concrete learning media functions to attract students' interest to the delivered learning material, (2) concrete learning media is useful in improving students' understanding on the given learning material, (3) concrete learning media can present valid and reliable data [2]. Generally, the function of concrete learning media can be described as (a) a tool to create effective learning condition, (b) an integral of the entire learning situation, (c) setting concrete basis and abstract concept so it could reduce verbal understanding, (d) developing students' learning motivation, (e) elevating learning quality [3].

Piaget's point of view highly suggests that the teacher to use concrete media or learning material so the students are able to accept the material in concrete operational cognitive stage. Instructional which is based on limited instructional behavior in the class, cognitively will orientate on students' ability to comprehend as many as possible learning material rather than empowering and optimizing students' cognitive structure ability for the sake of adapting with their environment. As the consequences, the students may acquire many separated knowledge, but these are not systemic and less powerful (meaningful, integrated, value-based, challenging, and making the students to be active). Based on the above background, this research aimed at describing the importance of teacher in 
reviewing instructional management at elementary school from Piaget's cognitive development theory and describing teacher's instructional behavior in managing instructional at elementary school reviewed from Piaget's cognitive development theory.

\section{METHODS}

This research used qualitative methods with concurrent embedded design. It combines qualitative and quantitative methods simultaneously, but the method weight was different. Quantitative method was used as primary method and qualitative method was the secondary method to find primary and secondary data. Subjects of this research were teachers of elementary school in Sukasada District, Buleleng Regency, Bali-Indonesia. They were chosen because teachers in this district were having problems in motivating students to study, which influenced students' learning achievement. Both primary and secondary data were collected through interview, observation, and documentation. The collected data were analyzed inductively and descriptively.

\section{RESULT AND DISCUSSION}

\section{A. The Nature of Children at Elementary School}

Indonesia's Regulation at UU No. 20 in 2003 concerning National Education System article 6 stated that every citizen aged 7 to 15 years old are obliged to follow elementary education. Moreover, Indonesia's Government Regulation No 17 in 2010 concerning Management and Implementation of Education article 69 paragraph 4 stated that all schools at elementary education level are obliged to accept all citizen aged 7 to 12 years old as their students up to the limit of its capacity.

Development era in this stage is called as elementary school era because in this era, a child is expected to get an essential elementary knowledge for selfpreparation and adaptation in adultery life. A child is expected to learn certain skills, both for curricular or extracurricular.

There are four skills that are expected to be mastered by elementary school students namely: independence, social, school and motoric cooperation skills [5]. 
There are some elementary school children characteristics that should be acknowledged by the teacher, in order to comprehend more the condition of the students especially in elementary school. Teacher should implement teaching method that is appropriate to the students' condition, so it is importance for the teachers to know their students' characteristics. First characteristic is the elementary school children like to play, second characteristic is happy to move, third characteristic is happy to work in group, and fourth characteristic is happy to feel or do something directly.

There are some development assignments at school [4], as follows: (1) learn to acquire physical skill to play, (2) learn to form positive attitude for themselves as a biological creature, (3) learn to socialize with their friends, (4) learn to play their roles based on gender, (5) learn basic skills in reading, writing and counting, (6) learn to develop daily concepts, (7) develop consciousness, (8) learn to have personal freedom, and (9) develop positive attitude upon institutions and social groups.

In relation to dimension of elementary school students' development, there are some development dimensions experienced by the elementary school students [5]. Those dimensions are physical development, emotional development, social development, mental-intellectual development, moral development, interest development, and personal development.

\section{B. Teacher's Instructional Behavior}

Behavior is a response or action that is conducted by an individual as a reaction of condition in his/her life. In $K B B I$ (Indonesian Big Dictionary) it is stated that instructional is teaching or learning (guidance or enlightenment). Instructional derived from instruction [6]. Further, Saylor and Alexander stated that instructional is defined as curriculum implementation or specifically refers to teaching learning process [6]. Therefore, it can be defined that instructional is the implementation of instructional as the implementation of curriculum.

Instructional development is a systematic way in identifying, developing and evaluating series of material and strategy which are directed to achieve a certain educational goal. Final result of the instructional development is an 
instructional system, that is an empirical developed teaching learning strategy and material which is consistently achieving certain instructional goal. This instructional development consists of a set of activities including planning, development, and evaluation upon the developed instructional system so after experiencing some revisions, the instructional system would satisfy the developer.

Based on Indonesia's Government Regulation No 41 of 2007, standard of learning process consists of planning instructional process, implementation of instructional process, evaluation of instructional process, and supervision of instructional process. It is intended to implement effective and efficient learning process. Related to this writing, it is only limited to the first three points.

Based on the analysis, teacher's instructional behavior was categorized into three steps, namely planning, implementation, and evaluation. In planning instructional, teacher's instructional behavior was categorized as very low $(33.3 \%)$, in implementing the instructional it was categorized as very vlow $(33.3 \%)$ and in evaluation step it was categorized as very low (54.2\%).

\section{Concrete Operational Learning at Elementary School}

Learning process is an educative interaction process related to its goal, directed to its goal and specifically conducted to reach the goal [7]. Instructional is a conducted activity to initiate, facilitate and improve the intensity and quality learning of the students [8]. Since instructional is a systematic and systemic effort to initiate, facilitate, and improve learning process, so instructional activity is closely related to the kinds of principal, learning, and the learning achievement.

In general, Piaget's cognitive development stages can be described in the specific characteristics in the scheme of the following table:

Table 1

Development stages with specific characteristics

\begin{tabular}{|c|c|c|c|c|}
\hline Stages & $\begin{array}{l}\text { Sensor- } \\
\text { motoric }\end{array}$ & $\begin{array}{c}\text { Pre- } \\
\text { operational }\end{array}$ & Concrete Operational & $\begin{array}{c}\text { Formal } \\
\text { Operational }\end{array}$ \\
\hline Ages & $0-2$ years old & 2-7 years old & $7-12$ years old & $\begin{array}{l}\text { Above } 12 \text { years } \\
\text { old }\end{array}$ \\
\hline Rationale & $\begin{array}{l}\text { Action and } \\
\text { imitating }\end{array}$ & $\begin{array}{l}\text { Symbolic/ } \\
\text { language and } \\
\text { intuitive, } \\
\text { imaginative }\end{array}$ & $\begin{array}{l}\text { Reversible } \\
\text { transformation and } \\
\text { permanency, still } \\
\text { concrete }\end{array}$ & $\begin{array}{l}\text { Deductive and } \\
\text { inductive, } \\
\text { abstract }\end{array}$ \\
\hline
\end{tabular}




\begin{tabular}{lllll}
$\begin{array}{l}\text { Moment of } \\
\text { thought }\end{array}$ & Now & $\begin{array}{l}\text { Start to "not } \\
\text { now" }\end{array}$ & Limited concreteness & $\begin{array}{l}\text { Leaving the } \\
\text { present and start } \\
\text { the future }\end{array}$ \\
$\begin{array}{l}\text { Other } \\
\text { characteris } \\
\text { tics }\end{array}$ & $\begin{array}{l}\text { Reflect, habit, } \\
\text { differentiation } \\
\text { of material } \\
\text { and result }\end{array}$ & Egocentric & $\begin{array}{l}\text { Decentering, series, } \\
\text { classification, concept, } \\
\text { number, time, } \\
\text { probability, causality }\end{array}$ & $\begin{array}{l}\text { pombortion, multi } \\
\text { reference, two } \\
\text { reversible, } \\
\text { flexible }\end{array}$ \\
\hline
\end{tabular}

Further, the stages of instructional process consisting of planning, implementing and evaluating the learning process which have adapted concrete operational stage of learning from Piaget's theory.

\section{1) Stage of Planning learning process}

1. Teacher formulates learning goals which are customized with students' ability to follow concrete learning.

2. Teacher arranges learning goals which adopt indicator from basic competency by customizing students' ability by modifying teaching method to ease the learning process

3. Teacher arranges learning material from the simpler to complex level, from easy to difficult and/or concrete to abstract based on the learning goals and arranges flexibility and difficulty of learning material by considering students' potential (including the fast and slow learner, high and low motivated students).

4. Teacher arranges learning material based on concrete life context and based on the science and technology development.

5. Teacher arranges relevant strategy, approach, and learning method to achieve learning goals and competency that should be mastered by the students so it will ease students' understanding to state the excepted learning.

6. Teacher allocates time proportionally by considering level of material complexity and/or needs of the students in every learning stages.

7. Teacher is able to choose learning sources/ learning media that help the students so it can be used to achieve learning goals or competency that want to achieve. 
8. Teacher can optimize more than one learning source by arranging learning so it can be attractive for the students and can be easily understood.

\section{2) Stage of Learning Process Implementation}

1. Teacher connects learning material with the students' prior knowledge by proposing problems close to the students' world.

2. Teacher creates freedom to the students to find their own answer of the given problems and does not give them the answer.

3. Teacher forms learning group and gives assignment or problem to the students in order to arise questions from the students.

4. Teacher involves students in experiment at the class to find a concept.

5. Teacher uses learning sources from concrete things and close to the students' environment in order to be easily understood.

6. Teacher uses tracker question to measure level of students' understanding.

7. Teacher provides help as empowerment from the learning of the students.

8. Teacher creates opportunity for the students to conclude their learning with their own language.

\section{3) Stage of Learning Evaluation}

1. Planning test that is appropriate with learning indicator to measure students' learning improvement from cognitive aspect.

2. Variety test so maximally able to measure every students' development from cognitive aspect.

3. Using authentic assessment (quiz, verbal question, assignment, and so on) to supervise students' learning development.

4. Implementing many portfolios in form of structured assignment

5. Using appropriate test based on the learning goals and material as arranged in lesson plan.

6. Using test analysis to identify easy, moderate or difficult topic/basic competency so it can be found the strength and weakness of every student for the remedial. 
7. Teacher uses many tests to provide feedback for the student about their learning development and becomes the basis of arranging further lesson plan.

\section{CONCLUSION}

Based on the finding of this research, it can be concluded that teachers in Sukasada District, Buleleng Regency, Bali-Indonesia had implemented their teaching without optimally considering the psychological developmental stages of Piaget. It could be seen from their achievements that were categorized as very low, in term of planning, implementation, and evaluation in their instructional behavior. Therefore, it is suggested that more intensive in-service training and seminar which emphasizing the importance of considering Piaget's cognitive development stages in teaching elementary school students should be conducted by the authorities in Buleleng such as the Principal of the schools, head of Education Office of Buleleng, as well as the teachers who need to improve their own understanding of this issue.

\section{Acknowledgements}

The author thanks the Principal of STKIP Suar Bangli for supporting and giving permission to conduct this research.

\section{REFERENCES}

[1] Nurkanca, Wayan. (2001). Perkembangan Jasmani dan Kejiwaan. Surabaya. Usaha Nasional.

[2] Hamdani (2005). Media Pembelajaran di Sekolah Dasar. Bandung: Alfabeta.

[3] Sumantri, Mulyani dkk. (2004). Media Pembelajaran. Jakarta: Rineka Cipta.

[4] LN, Syamsu Yusuf. (2004). Psikologi Perkembangan Anak dan Remaja. Bandung. Remaja Rosdakarya.

[5] Munandar, Utami. (1992). Mengembangkan Bakat dan Kreatifitas Anak Sekolah. Jakarta: PT. Gramedia Widiasarana Indonesia.

[6] Harjanto (2006). Perencanaan Pembelajaran. Rineka Cipta, Jakarta.

[7] Suastra, I.W. 2009. Pembelajaran Sains Terkini: Mendekatkan Siswa dengan Lingkungan Alamiah dan Sosial Budayanya. Universitas Pendidikan Ganesha. Singaraja. 
[8] Udin S. Winataputra, et al. Teori Belajar dan Pembelajaran. (Universitas Terbuka, Jakarta, 2007). 